\title{
HIGH SEROPREVALENCE OF BLUETONGUE IN SHEEP, GOATS AND CATTLE IN ASSIUT GOVERNORATE, EGYPT
}

\author{
Safaa S. Malek*; Sahar A. Abou EL-wafa** \\ *Infectious Diseases, Department of animal Medicine, Faculty of Veterinary Medicine, \\ Assiut University. \\ ** Department of Animal Medicine, Faculty of Veterinary Medicine, Assiut University.
}

\section{ABSTRACT}

A total of 552 serum samples of sheep, goats and cattle from different localities at Assiut governorate, Egypt were screened for qualitative analysis of the BTV antibodies using a commercial competitive ELISA (cELISA) kit. The results showed an overall percentage of BTV positive sheep, goats and cattle serum samples were $41.86 \%, 24 \%$ and $85.42 \%$ respectively. A highest percentage of seropositivity was found in Arab El-Awamer farm (100\%), followed by Abnoub( 63. 64\%), Sedfa(11. 43\%), veterinary teaching hospital (11.11\%), Aboteeg (3.57\%) and Bani zeed el akrad (0\%) respectively. From examined sera all over the four years from 2012 to 2015 indicates prevalence of BTV antibodies by (62.69\%) during the non hot months and (10\%) during the hot months, Female ruminants were more susceptible to the infection (61.29\%) than male( 21.67\%). The association between sex and prevalence of BT disease among ruminants observed in table (4). The results showed that the prevalence of BT was higher in female (61.29\%) than male (21.67\%). In conclusion, this study confirms the presence of blue tongue infection in Assiut Governorate, and cELISA were found to be sensitive and effective for screening of BTV group specific antibodies. The disease should be notifying its presence in Egypt since it was free from this disease and more studies should be attempets to estimate the serotype of blue tongue virus.

Key Words: Bluetongue, cELISA, sheep, goat, cattle, Seroprevalence, Assiut Governorate 


\section{INTRODUCTION}

Bluetongue virus (BTV) is the causative agent of bluetongue disease in sheep and cattle, an insect transmitted disease of ruminants (Erasmus., 1975). BTV belongs to Orbivirus genus of family Reoviridae it has double stranded segmented RNA genome having ten discrete segments The seven of these segments encode structural protein (VP1 to VP7) and the remaining three encode for non structural proteins (NS1, NS2, NS3 and NS3A), NS3 and NS3A are encoded by tenth segment (Scientific committee on animal health and animal welfare (SCAHAW) .2000). There are 24 distinct BTV serotypes and recently Toggenburg orbivirus (TOV) is proposed to be a 25th serotype (Hofmann et al., 2008) and, complete genome characterization of a 26th BTV serotype from Kuwait (Mann et al., 2011). It is a notifiable disease of the WorldOrganization for Animal Health (Office of international epizooties: OIE) due to its economic impact (WHO, 2010). Virus is transmitted within its vertebrate hosts via bites of culicoides species. The severity of infection depends on various factors, such as species, breed, age, nutritional and immune status of animals and environmental stresses as well as the virulence of BTV strain involved. Although clear differences in virulence of BTV isolates are known, the virulence determinants are still poorly defined (Maclachlan et al., 2009). Bluetongue is generally mild in indigenous sheep of Egypt since the classical symptoms of the disease are not commonly seen (Ayoub and Singh, 1970) except for abortion syndrome (Iman, 1990) so the detection of infected animals becomes difficult on the basis of clinical profiles or isolation of the virus. However, presence of BTV antibodies $\overline{\text { Kafrelsheikh Vet. Med. J. Vol. } 14 \text { No. } 1 \text { (2016) }}$ 
in a herd indicates the presence of viral infection (Jain et al., 1992) In order to overcome serological crossreactions among orbivirus serogroups, which can hinder the accurate diagnosis of bluetongue virus (BTV) infection of livestock, a blocking ELISA (B-ELISA) incorporating a monoclonal antibody with specificity for the BTV serogroup was developed (Lunt et al., 1988) The competitive enzyme linked immunosorbent assay (cELISA) is a superior test for serologic diagnosis of BTV infection of ruminants because it requires significantly less time to run, and provide objective results (Reddington et al., 1991). It is also approved by OIE for testing BTV infection in international trade of livestock. In the present study, we have assayed seroprevalence in sheep, goats and cattle at different localities in Assiut governorate, Egypt using commercially available competitive ELISA kit.

\section{MATERIALS AND METHODS}

\section{a. Serum samples:}

A total of 552 field sera were randomly collected from sheep (258), goats (150) and cattle (144) from different localities at Assiut Governorate, Egypt, from 2012 to 2015 . No record of bluetongue activity has ever been reported in these localities. These sera were stored at $-20^{\circ}$ $\mathrm{C}$ in small aliquots till used for the detection of BTV-group specific antibodies using competitive ELISA (cELISA).

\section{b. Competitive Enzyme-linked Immunosorbent Assay (cELISA):}

The Bluetongue Competitive ELISA Kit: (INGEZIM BTV COMPAC 2. 0 Prod Ref: 12. BTV.K3 - Batch n. 241115 - MADRID (SPAIN)) were used. The test is based on the detection of antibodies 
specific to the highly conserved segment 7 (VP7) of BTV. It is therefore designed to detect infection by any type of BTV and/or vaccination by any vaccine presenting the VP7 antigen. The test was carried out as described in the protocol supplied by the manufacturers.

\section{- CUT OFF CALCULATION:}

Cut off $(-)=0.65 \times$ Negative control

Cut off $(+)=0.6 \times$ Negative control

\section{- RESULTS INTERPRETATION:}

Samples will be considered positive when the OD at $450 \mathrm{~nm}$ was equal or lower than the positive cut off (60\% of the negative control). Samples will be considered negative when the OD at 450nm was equal or higher than the negative cut off (65\% of negative control).

\section{RESULTS}

A serological survey involving 552 serum samples (258 sheep, 150goats and 144 cattle) from different localities at Assiut governorate, Egypt was carried out employing cELISA for qualitative analysis of the BT antibodies. 552 samples (48.37\%). From examined sera for each species 58.14\% (108/258) sheep, 24\% (36/150) goats and 85.42\% $(123 / 144)$ cattle were positive for BTV - antibodies, as shown in Table (1). From examined sera all over the four years from 2012 to 2015 indicates prevalence of BTV antibodies by $62.69 \%$ (252/402) during the non hot months and 10\% (15/150) during the hot months, table (2). a high percentage BT antibodies were detected in Arab El- Awamer farm100\% (123/ 123), followed by Abnoub 63. 64\% (126/ 198), Sedfa11. 43\% (12/ 105), veterinary teaching hospital11.11\% (3/ 27), 
High Seroprevalence Of Bluetongue In Sheep ...

Aboteeg 3.57\% (3/ 84) and Bani zeed el akrad 0\% (0/ 15) respectively, as shown in table (3). The association between sex and prevalence of BT disease among ruminants observed in table (4). The results showed that the prevalence of BT was higher in female (61.29\%) than male (21.67\%).

Table (1): Seroprevalence of BT in sheep, goats and cattle as determined by cELISA.

\begin{tabular}{|c|c|c|c|}
\hline Species of tested animals & Number of serum samples & positive & $\%$ of positive \\
\hline sheep & 258 & 108 & 41.86 \\
\hline goats & 150 & 36 & 24 \\
\hline cattle & 144 & $123 * *$ & 85.42 \\
\hline Total & 552 & 267 & 48.37 \\
\hline
\end{tabular}

Chi- square $=119.18$

** Highly significant at $\mathrm{p}<0.01$

Table (2): Seasonal distribution of BT all over the four years 2012 to 2015.

\begin{tabular}{|c||c||c||c|}
\hline months & Number of examined sera & Number of positive sera & \% of infection \\
\hline \hline Non- hot- months & 402 & $252 * *$ & 62.69 \\
\hline Hot months & 150 & 15 & 10 \\
\hline \hline Total & $\mathbf{5 5 2}$ & $\mathbf{2 6 7}$ & $\mathbf{4 8 . 3 7}$ \\
\hline
\end{tabular}

Chi- square $=121.42$

$* *$ Highly significant at $\mathrm{p}<0.01$

Hot months: June, July, and August.

Non- hot- months: From September to March.

Table (3): Seroprevalence of BT in different localities in Assiut Governorate as determined by cELISA.

\begin{tabular}{|c|c|c|c|}
\hline Locality & Total Examined sera & Total positive sera & \% of positive sera \\
\hline Arab El- Awamer farm & 123 & $123 * *$ & 100 \\
\hline Abnoub & 198 & 126 & 63.64 \\
\hline Sedfa & 105 & 12 & 11.43 \\
\hline Vterinary teatching hospital & 27 & 3 & 11.11 \\
\hline Aboteeg & 84 & 3 & 3.57 \\
\hline Bani zeed el akrad & 15 & 0 & 0 \\
\hline Total & 552 & 267 & 48.37 \\
\hline
\end{tabular}

Chi- square $=303.71$

** Highly significant at $\mathrm{p}<0.01$

$\overline{\text { Kafrelsheikh Vet. Med. J. Vol. } 14 \text { No. } 1 \text { (2016) }}$ 
Table (4): Seroprevalence of BT in both sexes among ruminants in Assiut Governorate as determined by cELISA.

\begin{tabular}{|c||c||c|c|}
\hline Sex & Number of examined sera & Number of positive sera & \% of infection \\
\hline \hline Male & 180 & 39 & 21.67 \\
\hline Female & 372 & $228 * *$ & 61.29 \\
\hline \hline Total & $\mathbf{5 5 2}$ & $\mathbf{2 6 7}$ & $\mathbf{4 8 . 3 7}$ \\
\hline
\end{tabular}

Chi- square $=76.26$

** Highly significant at $\mathrm{p}<0.01$

\section{DISCUSSION}

In recent years vector-borne diseases (VBDs) are (re) emerging and spreading across the world, having a profound impact on human and animal health, ecology, socio-economic and disease management (Jones et al., 2008). Bluetongue affects both domestic and wild ruminants, and its origin is probably African ruminants. It was first identified in South African Merino sheep in the late 18th century (Gerdes, 2004). Various techniques have been used to detect antibodies against BTV. Only AGID and competitive-ELISA are recommended as prescribed tests for international trade in the OIE Manual of Standards for Diagnostic Tests and Vaccines (WHO, 2010). In Egypt, there is no vaccination program is running or used, so positive serum samples means that BTV-specific antibodies which are still circulating in the tested animals without any detectable signs is due to subclinical infection (Maclachlan et al., 2009). Although in 2008 Egypt declared free from BT, it has notice the presence of BT infection in the last few years. No available data on disease history in Egypt. The disease has become a threatening disease as it may attack animals in the form of massive outbreaks due to animal exportation during Eid Al Adha, which is a major feast in Egypt and due to the

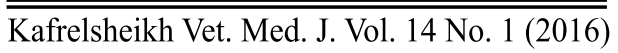


climate change as high temperature and humidity (Kawther, 2012). This study estimates the prevalence and distribution of antibodies to BTV in different localities at Assiut governorate, Egypt. Our results revealed high seroprevalence $(48.37 \%)$ of BTV infection which was comparable to that has been described amongst ruminants done in Assiut (1.1\%) by using agar gel immune- precipitation test (AGPT) (Mahmoud and Manal, 2014) in Egypt (16.5\%) (El-Bagoury et al., 2013), in regions of Saudi Arabia (47.3\%) (Yousef et al., 2012), Turkey (29.5\%) (Gür, 2008), India (up to 45.7\%) (Sreenivasulu et al., 2004), and low than in different areas of north-east of Iran (89.2\%) (Najarnezhad and Rajae, 2013), Pakistan (48.8\%) (Akhtar et al., 1997). Due to the large number of circulating BTV serotypes, it is generally impossible to predict the serotype for a specific season or area. Furthermore, several serotypes tend to circulate simultaneously (Verwoerd and Erasmus, 2004). Dealing with seasonal variation of blue tongue among infected ruminant, the present study showed that there was a relationship between the rate of BT infection and the atmosphere temperature ,so in non- hot months from September to March the infection rate was (62.69\%) and in the hot months from June, July, and August was (10\%) as in table (2), this may be contributed to the rapid breeding and multiplication of the vector in these months as in Egypt the atmosphere characterized by high humidity and moderate temperature (Temperature is about $29 \mathrm{C}^{\circ}$ and relative humidity is about $72 \%$-Meteorological office), where culicoides were found to build up a peak in these months (Jain et al., 1992). This result was come in agreement with many authors as in Egypt the highest percent of BTV antibody were detected in autumn (El-Bagoury et al., 
2013). The highest proportion of seropositives in different livestock in Arab El- Awamer farm followed by Abnoub, Sedfa, Veterinary teaching hospital, Aboteeg and Bani zeed el akrad respectively could be attributed to climatic factors that favor the maintenance and recirculation of the BTV in its vertebrate and non-vertebrate hosts in addition to unrestricted movement of animal population between these localities and the importation from Asia and the Horn of Africa (Ethiopia, Somalia, Eritrea and Djibouti) where the enzootic nature of BTV in large regions of the African continent is reported (Dungu et al., 2004) and also there were possibility of windborne carriage of infected Culicoides from distant endemic areas (Gibbs and Greiner, 1988). The association between sexes with prevalence rate of BT in ruminants was also observed and females showed higher prevalence rate than males $61.29 \%, 21.67 \%$ respectively as in table (4). An explanation in this respect may afford on basis that the presence of male animals for a long time in closed chamber (indoors) for fattening purpose which lead to less exposure to biting with insect vectors. In contrast, females were most of time under stress of recurrent pregnancy and parturition which lead to lowering of resistance toward the infection.

\section{CONCLUSION}

This study confirms the presence of blue tongue infection in Assiut Governorate, Egypt, and cELISA were found to be sensitive and effective for screening of BTV group specific antibodies. The disease should be notifying its presence in Egypt since it was free from this disease and more studies should be attempts to estimate the serotype of blue tongue virus. 


\section{REFERENCES}

- Akhtar S., Djallem N., Shad G., Thiemo O. (1997): Bluetongue virus seropositivity in sheep flocks inNorth West Frontier Province, Pakistan. Prev. Vet. Med., 29:293-8.

- Ayoub, H. and singh, k. v. (1970): Identification of bluetongue in Egypt. Bull.Epizoot.Dis.Afr.18:123-136.

- Dungu B., Gerdes T., Smit T. (2004): The use of vaccination in the control of bluetongue in southern Africa. Vet. Ital., 40:616-622.

- El-Bagoury, G.F., El-Nahas, E.M., Asmaa Moneer,. and Nawal. M.A. Youssef. (2013): Prevalence of antibodies to blue tongue virus in small and large ruminants at different provinces of Egypt. Benha veterinary medical journal, Vol 25, NO. 1:100-105.

- Erasmus, B.J. (1975): Bluetongue in sheep and goats. Aust Vet. J., 51:165-170

- Gerdes G. H. (2004): A South African overview of the virus, vectors, surveillance and unique features of bluetongue. Vet. Ital., 40:39-42.

- Gibbs, E. P. J. and Greiner, E. C. (1988): Bluetongue and Epizootic Hemorrhagic Disease. In The Arboviruses: Epidemiology and Ecology, Vol. II, TP Monath (ed.), CRC Press, Boca Raton, pp. 39-70.

- Gür S. (2008): A serologic investigation of bluetongue virus (BTV) in cattle, sheep and gazelle Subgutturosa subgutturosa in southeastern Turkey. Trop. Anim. Health Prod., 40:217-21.

- Hofmann, M.A., Renzullo, S., Mader, M., Chaignat, V., Worwa, G. and Thuer, B. (2008): Genetic characterization of Toggenburg orbivirus, a new bluetongue virus, from goats, Switzerland. Emerg. Infect. Dis. 14: 1855-1861. 
- Iman, M. Bastawecy (1990): Studies on bluetongue virus and its related viruses. M. V. SC., Thesis, Fac. Vet. Med., Cairo university.

- Jain, N.C., Gupta, Y. and Prasad, G. (1992): Blutongue virus antibodies in buffaloes and cattle in haryana state of India.In: Bluetongue,African Horse sickness and related orbiviruses. Proc. Second International Symposium on orbiviruses, Paris,17-21 June,1991.CRC Pres,Boca Raton.florida.p.188-192.

- Jones, K., N. G. Patel, M. A. Levy, A. Storeygard, D. Balk, J. L. Gittleman and P. Dazak, (2008): Global trends in emerging infectious diseases. Nature, 451: 990- 993.

- Kawther S. Z. (2012): Bluetongue Infection in Small Ruminants in Egypt. Academic Journal of Animal Diseases 1(3): 21-26.

- Lunt, R. A., White, J.R. and Blacksell, S. D. (1988): Evaluation of a Monoclonal Antibody Blocking ELISA for the Detection of Groupspecific Antibodies to Bluetongue Virus in Experimental and Field Sera. J. Gen. Virol. 69: 2729-2740.

- Maan, S., Maan, N.S., Nomikou, K., Batten, C., Antony, F., Belaganahalli, M.N., Samy, A.M., Reda, A.A., Al-Rashid S.A., El Batel, M., Oura, C.A. and Mertens, P.P. (2011): Novel bluetongue virus serotype from Kuwait. Emerg Infect. Dis. 17:886-889.

- MacLachlan, N.J., Drew, C.P., Darpel, K.E., Worwa, G., (2009): The pathology and pathogenesis of bluetongue. Journal of Comparative Pathology 141 : 1-16.

- Mahmoud, M. A. and Manal H. K. (2014): Seroprevalence of bluetongue in sheep and goats in Egypt. Veterinary World, EISSN: 2231-0916. 
- Najarnezhad, $V$ and Rajae, M. (2013): Seroepidemiology of bluetongue disease in small ruminants of northeast of Iran. Asian Pac J Trop Biomed 2013; 3(6): 492-495.

- Reddington, J. J., Reddington, G.M. and Maclachlan, N.J. (1991): A competitive ELISA for detection of antibodies to thegroup antigen of bluetongue virus. J. Vet. Diagn Invest, 3:144-147.

- Scientific committee on animal health and animal welfare (SCAHAW) June (2000): Possible use of vaccination against bluetongue in Europe. Europian commission, health and consumer protection directorate general, 1- 25.

- Sreenivasulu D., Subba Rao M. V., Reddy Y. N., GardG. P. (2004): Overview of bluetongue disease, viruses, vectors, surveillance and unique features: the Indian subcontinent and adjacent regions. Vet. Ital., 40:73-77.

- Verwoerd D. and Erasmus B. J. (2004): Bluetongue In: Infectious diseases of livestock. (Coetzer JA \&Tustin RC, eds) Second Ed. Cape Town, Oxford University Press; pp.1201-1220.

- World Organization for Animal Health (WHO) (2010): Bluetongue,. Chapter 8.3, Terrestrial Animal Health Code, 19th edition OIE, paris 448-463.

- Yousef, M. R., Al-Eesa, A. A., Al-Blowi, M. H. (2012): High seroprevalence of bluetongue virus antibodies in Sheep, Goats, Cattle and Camel in different districts of Saudi Arabia. Vet. World, 5(7): 389-393. 
الانتشار المصلي العالي من مرض اللسان الأزرق في الأغنام والماعز و الأبقار في محافظة أسيوط ، مصر الان فرئ

تم عمل مسح سيرولوجى لإجمالي 552 عينة مصلية من الأغنام ،الماعز والأبقار فى مناطق مختلفة في محافظة أسيوط، مصر للتحليل الكيفي للأجسام المضادة لفيروس اللسان الأزرق باستخدام اختبار الإليزا التتافسي التجاري. أوضحت النتائج أن النسبة الايجابية الكلية لفيروس اللسان الأزرق فى كل من العينات المصلية للأغنام و والماعز والأبقار كانت 41.86٪، 24٪ و 85.42\% على التوالي. تم العثور على أعلى نسبة للإصـابة في مزرعة عرب العوامر (100٪)، تليها أبنوب (64. 63٪)، صدفا(11.43\%)، المستشفى التعليمي البيطري (11.11\%) ،أبوتيج (3.57\%) و بنيزيدالأكراد (0\%) على التوالي. وقد أثنارت العينات المصلية التي فحصت على مدار السنوات الأربعة 2012-2015 يدل على انتشار الأجسام المضادة لفيروس اللسان الأزرق بنسبة (62. 69٪) خلال الأثشهر غير الساخنة و (10\%) خـلال الأثـهر الحسارة، وكانـت الإنـاث أكثر عرضــة للعـدوى (61.29\% ) مـن الـذكور (21.67٪). وفي الختام ، فإن هذه الدراسة تؤكد وجود عدوى اللسان الأزرق في محافظة أسيوط ، وان اختبـار الإليزا التتافسي كـان ذو حساسية وفاعليـة في المسـح السيرولوجى الأجسـام المضــادة للجمـع الخاص بفيروس اللسان الأزرق BTV ـ المرض يجب إثعار وجوده في مصر لأنها كانت خالية من هذا المرض والمزيد من الدراسات ينبغي أن تتم لتقدير العترة من فيروس اللسان الأزرق. 